\title{
STUDI KANDUNGAN LOGAM BERAT CADMIUM (Cd) PADA KERANG HIJAU (Mytilus viridis) YANG DIJUAL DI PASAR TRADISIONAL PABEAN KOTA SURABAYA
}

\author{
Ita Noryani, Koerniasari, AT. Diana Nerawati
}

\begin{abstract}
Green mussels ( Perna viridis/Mytilus viridis ) live in tropical seas such as those in Indonesia. Sea is one of waters that receive the negative impact of pollutant wastes produced by human activities. Heavy metals are among those pollutants mostly found in waters as the consequence of industrial waste and domestic waste contamination. Cadmium has the highest enzyme activity among those other heavy metals, so that the existence of cadmium in green mussels may endanger one's health since it can cause a damage to urinary, respiration, circulation, and reproduction systems.

The aim of this study is to learn about the cadmium content in green mussels from Kenjeran, Sidoarjo and Madura sold at Pabean Market of Surabaya. The method employed in this study is descriptive method based on laboratory test result. The sampling is done by means of purposive sampling and there are 6 samples taken from 6 green mussels sellers.

It can be concluded from this study that green mussels from 3 regions namely Sidoarjo, Kenjeran and Madura sold at Pabean Market positively show pink color after being qualitatively tested with color test in the laboratory, while quantitatively it is proven that cadmium content in those green mussels is above the floating limit score of $0,2 \mathrm{ppm}$ established by SNI under No. 01-2896-1998. The cadmium content in green mussels from Kenjeran is of 0,369 ppm and 0,348 ppm, Sidoarjo is of 0,258 ppm and 0,267 ppm, and Madura is of $0,212 \mathrm{ppm}$ and $0,217 \mathrm{ppm}$.

It is suggested that people must be very careful while consuming those green mussels from Kenjeran, Madura or Sidoarjo which content of cadmium is over the permitted limit established by SNI since it may cause health problem and body damage. One way to reduce the risk of cadmium danger is to soak the mussels in an acid solution of cooking star fruit and lime before cooking them.
\end{abstract}

\section{PENDAHULUAN}

Kerang hijau (Perna viridis/Mytilus viridis) adalah salah satu bahan pangan jenis perikanan non - ikan yang telah lama dikonsumsi oleh penduduk Indonesia karena harga kerang hijau yang terjangkau dan bergizi tinggi mengandung protein $21,9 \%$, lemak $14,5 \%$ dan karbohidrat $18,5 \%$.

Kerang hijau (Perna viridis/Mytilus viridis) hidup di laut tropis seperti Indonesia. Laut merupakan salah satu perairan yang dapat menerima dampak negatif dari aktifitas manusia yang berupa bahan pencemar. Bahan pencemar yang masuk ke dalam perairan berasal dari limbah organik, logam berat dan minyak. Logam berat merupakan bahan pencemar yang banyak ditemukan di perairan akibat masukan limbah industri dan limbah perkotaan (Ghufran,2011:132).

Logam berat seperti Merkuri $(\mathrm{Hg})$, cadmium (Cd) dan timbal $(\mathrm{Pb})$ merupakan jenis logam non essensial, yaitu jenis logam yang bersifat toksik bagi manusia meskipun dalam kadar rendah. Cadmium adalah logam yang memiliki aktivitas enzim tertinggi diantara logam berat lainnya. Cadmium banyak dipakai dalam proses electroplating dan sebagai stabilizer dalam pembuatan polyvynil khlorida (Slamet, 1994:114). Berdasarkan Standar Nasional Indonesia No. 01-2896-1998 tentang batas maksimum cemaran logam berat cadmium pada hewan laut sebesar $0,2 \mathrm{mg} / \mathrm{kg}(\mathrm{ppm})$, konsentrasi logam berat cadmium yang berada diatas nilai ambang batas normal akan menyebabkan keracunan serta mengakibatkan kerusakan pada beberapa organ, antara lain :ginjal, liver, sistem imunitas, sistem susunan saraf dan darah (Palar, 2004:124). Pasar Pabean merupakan pasar tradisional yang terletak di cabang utara tepatnya di jalan Pabean Surabaya. Penelitian dilakukan di pasar ini dikarenakan merupakan pusat komoditi ikan segar, kerang - kerangan, bumbu dan rempah - rempah di wilayah Surabaya. 
Kerang yang dijual di Pasar Pabean berasal dari beberapa daerah seperti Kenjeran, Madura, dan Sidoarjo.

Berdasarkan latar belakang tersebut maka dalarn penelitian dilakukan uji kualitatif dan uji kuantitatif cadmium (Cd) untuk mengetahui adanya kandungan cadmium pada kerang hijau yang berasal dari Kenjeran, Sidoarjo, dan Madura yang dijual di pasar Pabean Surabaya.

\section{METODE PENELITIAN}

Jenis penelitian yang dilakukan berdasarkan analisis data termasuk penelitian deskriptif. Deskriptif dilakukan terhadap sekumpulan obyek yang bertujuan untuk melihat gambaran fenomena yang terjadi di dalam suatu populasi tertentu (Notoatmodjo, 2010:138). Peneliti ingin menggambarkan cadmium pada kerang hijau yang dijual di Pasar Pabean Surabaya.

Populasi dalam penelitian adalah kerang hijau yang berasal dari Kota Sidoarjo, Madura, dan Kenjeran. Kerang hijau tersebut dijual oleh 6 pedagang kerang hijau yang terdapat di dalam Pasar Pabean Surabaya.

Sampel dari penelitian diambil dengan menggunakan teknik Purposive Sampling dengan kriteria yaitu kerang yang dijual di Pasar Pabean Surabaya yang berasal dari 3 wilayah yaitu Sidoarjo, Madura, dan Kenjeran. Besar sampel diambil masingmasing wilayah 2, sehingga besar sampel semuanya 6 sampel. Kemudian sampel diuji secara kualitatif dan kuantitatif.

Teknik pengumpulan data yang digunakan antara lain, wawancara untuk memperoleh data-data khusus (identifikasi) kerang hijau yang dijual oleh 6 pedagang yang berasal dari Kota Sidoarjo, Madura dan Kenjeran, serta uji laboratorium melalui pengambilan sampel kerang hijau di Pasar Pabean Surabaya dengan menggunakan lembar hasil uji laboratorium kerang hijau yang dijual di Pasar Pabean Surabaya.

Metode analisis data yang digunakan dalam penelitian ini adalah analisis deskriptif melalui tahapan pemasukan data hasil laboratorium 6 sampel ke dalam tabel lalu membandingkan data dengan Standar Nasional Indonesia No. 01-2896-1998.

\section{HASIL PENELITIAN DAN PEMBAHASAN}

Lokasi yang digunakan untuk penelitian ini adalah Pasar Pabean Surabaya. Pasar Pabean Surabaya terletak di Jl. Songoyudan 77 di bawah Kelurahan Nyamplungan, Kecamatan Pabean Cantikan. Bangunan Pasar Pabean terdiri dari 3 bagian. Pasar ini mempunyai berbagai macam komoditas, diantaranya komoditas utamanya berupa mracangan, palen, ikan, dan hasil bumi lainnya. Pada bagian komoditas mracangan biasanya buka setiap hari pada pukul $04.00-16.00$. Sedangkan bagian komoditas perikanan buka setiap hari pada pukul $18.00-06.00$. Kerang yang diteliti berasal dari 3 wilayah yaitu Madura, Sidoarjo, dan Kenjeran dan kemudian dipasarkan di Pasar Pabean.

Perairan Kenjeran, Surabaya merupakan perairan umum. Pantai Kenjeran terletak di sebelah utara kota surabaya. Perairan Kenjeran merupakan beberapa muara sungai yang ada di Surabaya, antara lain : Kali Mas, Kali Tebu, Kali Kedung Cowek, Kali Kenjeran, Kali Kalidami, Kali Wonokromo, Kali Wonorejo. Sungai - sungai tersebut merupakan saluran pembuangan limbah baik yang berasal dari industri dan rumah tangga.

Branta Pesisir Pamekasan, Madura merupakan daerah perairan umum yang digunakan sebagai area pelabuhan masyarakat sekitar. Daerah Branta Pesisir merupakan salah satu kecamatan yang terdapat pada Kabupaten Pamekasan, Madura. Daerah Branta Pesisir Pamekasan, Madura bukan termasuk daerah industri seperti halnya daerah Kenjeran Surabaya. Perairan Kenjeran, Surabaya dengan Branta Pesisir Pamekasan, Madura dipisahkan oleh Selat Madura.

Perairan Sidoarjo merupakan perairan laut yang terletak di antara dua muara sungai yaitu sungai porong dan sungai Surabaya. Kondisi perairan Sidoarjo dipengaruhi oleh dua aliran sungai utama tersebut. Selain dari dua sungai besar tersebut di perairan Sidoarjo bermuara beberapa aliran sungai diantaranya sungai Jabon, sungai Ketingan dan sungai Kendil berada di kecamatan sidoarjo. Sungai Tambak Agung, Sungai Gisik, Sungai Buntung serta Sungai Tambak Oso yang berada di kecamatan Sedati yang seluruhnya bermuara di perairan Sidoarjo. Cadmium dapat ditemukan dari limbah 
domestik, pertanian, dan hasil buangan limbah industri yang berada di Sidoarjo yang membuang limbahnya di aliran perairan Sidoarjo.

Kerang hijau yang dijual di Pasar Pabean Surabaya berasal dari 3 wilayah yaitu Sidoarjo, Kenjeran, dan Madura. Pasokan kerang hijau tidak setiap hari ada, 2 atau 3 hari kemudian akan dipasok lagi. Pemasok langsung dari nelayan sendiri yang menjual ke pedagang kerang hijau yang berada di Pasar Pabean Surabaya.

\section{Hasil Uji Laboratorium}

TABEL. 1

KADAR CADMIUM PADA 6 SAMPEL KERANG HIJAU DI PASAR TRADISIONAL PABEAN SURABAYA

\begin{tabular}{|c|c|c|}
\hline No. & Kode Sampel & Hasil $(\mathrm{mg} / \mathrm{kg})$ \\
\hline 1. & Kenji-1 & 0,369 \\
\hline 2. & Kenji-2 & 0,348 \\
\hline 3. & Mdr-1 & 0,212 \\
\hline 4. & Mdr-2 & 0,217 \\
\hline 5. & Sda-1 & 0,258 \\
\hline 6. & Sda-2 & 0,267 \\
\hline
\end{tabular}

Sumber : Data Primer BBLK Surabaya 2013

Berdasarkan tabel. 1 hasil
pemeriksaan dengan menggunakan
metode AAS (Atomic Absorbtion Spectrophotometry) menunjukkan bahwa 6 sampel kerang hijau di pasar tradisional Pabean Surabaya kadar cadmium pada kerang hijau semua telah melebihi nilai ambang batas berdasarkan Standar Nasional Indonesia No. 01-2896-1998 tentang batas maksimum cemaran logam berat cadmium pada kerang sebesar 0,2 $\mathrm{mg} / \mathrm{kg}$ (ppm). Kadar cadmium yang tertinggi adalah kerang hijau yang berasal dari Kenjeran sebesar 0,369 mg/kg (ppm).

Faktor yang mempengaruhi tinggi rendahnya derajat akumulasi logam berat sama dengan faktor yang mempengaruhi akumulasi logam pada hewan air lainnya. Perbedaannya, jenis kerang dapat mengakumulasi logam lebih besar daripada hewan air lainnya karena sifatnya yang menetap, lambat untuk dapat menghindarkan diri dari pengaruh polusi, dan mempunyai toleransi yang tinggi terhadap konsentrasi logam tertentu.
Karena itu jenis kerang ini merupakan indikator yang sangat baik untuk memonitor suatu pencemaran lingkungan (Darmono, 2001:105).

Kadar cadmium pada kerang hijau melebihi NAB, dikarenakan bahwa biota yang memiliki mobilitas tinggi akan sulit untuk mengakumulasi logam berat. Kandungan cadmium kerang hijau tertinggi pada perairan Kenjeran sebesar 0,369 $\mathrm{mg} / \mathrm{kg}$. Pencemaran logam berat yang terjadi di Perairan Kenjeran terutama disebabkan oleh pembuangan limbah dari industri yang menggunakan logam berat dalam proses produksi seperti industri pengolah logam, cat dan pewarna, baterai, percetakan, kertas, tekstil, peralatan listrik dan sebagainya.

Pada daerah Pamekasan, Madura kadar cadmium kerang hijau berada di atas ambang cemaran logam berat SNI $(0,2$ $\mathrm{mg} / \mathrm{kg}$ ) yaitu sebesar $0,217 \mathrm{mg} / \mathrm{kg}$. Pencemaran yang terdapat pada perairan Pamekasan Madura disebabkan adanya proses pembuatan dan perbaikan armada 
laut oleh nelayan yang meliputi pengecatan ulang kapal atau perahu nelayan tersebut. Proses pencemaran logam berat cadmium yang terdapat pada perairan Pamekasan Madura juga disebabkan oleh tumpahan minyak yang berasal dari kapal dan pencemaran minyak di laut yang berasal dari daratan sebagai akibat terbawa arus air hujan dan pembuangan sampah (Darmono, 2001:49). Adanya proses pelapukan serta pestisida yang ada pada area pertanian. Sesuai dengan pendapat Palar (2004:118) menyatakan bahwa proses pemasukan cadmium yang ada di perairan dapat terbentuk melalui pelapukan secara alami dengan cara melepaskan unsur logam berat cadmium yang ada pada lapisan bumi.

Pada daerah Sidoarjo kadar cadmium pada kerang hijau berada di atas ambang SNI $(0,2 \mathrm{mg} / \mathrm{kg})$ yaitu $0,267 \mathrm{mg} / \mathrm{kg}$. Pencemaran yang terdapat pada perairan Sidoarjo disebabkan oleh Kondisi perairan Sidoarjo dipengaruhi dua aliran sungai Surabaya dan sungai Porong. Kedua sungai tersebut merupakan sungai besar yang melewati kota-kota besar di Jawa Timur. Selain dari dua sungai besar tersebut di perairan Sidoarjo bermuara beberapa aliran sungai diantaranya sungai Jabon, sungai Ketingan dan sungai Kendil berada di kecamatan Sidoarjo. Sungai Tambak Agung, Sungai Gisik, Sungai Buntung serta Sungai Tambak Oso yang berada di kecamatan Sedati yang seluruhnya bermuara di perairan Sidoarjo. Pencemaran terjadi karena pembuangan limbah industri yang berada di sekitar perairan Sidoarjo dan limbah domestik serta buangan hasil kegiatan warga.

Ada perbedaan kandungan cadmium secara kuantitatif pada kerang hijau yang berasal dari Sidoarjo, Madura, dan Kenjeran setelah dilakukan uji laboratorium di Balai Besar Laboratorium Kesehatan Surabaya. Kandungan cadmium pada kerang hijau yang tertinggi yaitu kerang hijau yang berasal dari Kenjeran. Kenjeran yaitu muara dari sungai yang ada disekitarnya yang dapat menerima limbah industri, domestik, pertanian, transportasi, laundry, pengolahan roti, perbaikan perahu seperti pengecetan ulang, tumpahan bahan bakar yang masuk ke dalam perairan Kenjeran yang dapat menyebabkan sebagai salah satu penyebab tingginya kandungan cadmium pada kerang hijau. Kadar cadmium pada kerang hijau yang berasal dari Sidoarjo merupakan urutan kedua setelah Kenjeran, jumlah industri yang banyak di Surabaya dibandingkan dengan Sidoarjo, semakin banyak industri maka akan semakin banyak pula limbah yang di buanag di perairan tersebut. Kadar cadmium di perairan Sidoarjo dapat berasal dari limbah industri, domestik, pertanian, usaha bakery dan laundry. Kadar cadmium pada kerang hijau yang berasal dari Madura terendah karena Madura bukan daerah industri.

Upaya untuk mengurangi kandungan konsentrasi logam berat bisa dilakukan antara lain dengan mengontrol sumber keluaran sistem saluran air pembuang limbahnya, tetapi cara ini mempunyai kelemahan yaitu untuk mengenali suatu sumber keluaran di wilayah pusat industri jelas akan sulit (Tresna, 2000:53).

Adanya kandungan cadmium pada kerang hijau dapat berbahaya bagi kesehatan. Sesuai pendapat Palar (2004:123) sistem - sistem tubuh yang dapat dirusak oleh keracunan kronis logam $\mathrm{Cd}$ ini adalah pada sistem urinaria (ginjal), sistem respirasi (pernapasan/paru - paru), sistem sirkulasi (darah) dan jantung, kelenjar reproduksi, sistem penciuman dan bahkan dapat mengakibatkan kerapuhan pada tulang. Salah satu cara untuk mengurangi kadar cadmium pada kerang hijau yaitu dengan dilakukan perendaman sebelum pengolahan dengan menggunakan larutan asam belimbing wuluh, yaitu perendaman daging kerang hijau $600 \mathrm{gr}$ dengan konsentrasi asam belimbing wuluh $15 \%$ dan air 3 It selama 60 menit dapat menurunkan kadar cadmium sebesar 94,73\% (Hudaya, 2010). Sedangkan perendaman dengan larutan jeruk nipis, yaitu perendaman daging kerang hijau $500 \mathrm{gr}$ dengan konsentrasi asam jeruk nipis $25 \%$ dan air 2 It selama 90 menit dapat menurunkan kadar cadmium sebesar 47,09\% (Wibowo, 2011). 


\section{KESIMPULAN}

1. Kerang hijau telah melebihi nilai ambang batas maksimum cemaran logam berat berdasarkan SNI No. 012896-1998 sebesar 0,2 $\mathrm{mg} / \mathrm{kg}$ sehingga tidak aman untuk dikonsumsi.

2. Kandungan logam berat cadmium pada kerang hijau yang dijual di Pasar Pabean telah melebihi ambang batas dari SNI $(0,2 \mathrm{mg} / \mathrm{kg})$. Kandungan cadmium pada kerang hijau di perairan Kenjeran sebesar 0,369 $\mathrm{mg} / \mathrm{kg}$ (ppm) dan 0,348 mg/kg (ppm). Di perairan Branta Pesisir Pamekasan, Madura sebesar $0,212 \mathrm{mg} / \mathrm{kg}(\mathrm{ppm})$ dan $0,217 \mathrm{mg} / \mathrm{kg}(\mathrm{ppm})$. Di perairan Sidoarjo sebesar $0,258 \mathrm{mg} / \mathrm{kg}$ (ppm) dan $0,267 \mathrm{mg} / \mathrm{kg}$ (ppm).

\section{SARAN}

1. Masyarakat hendaknya berhati-hati dalam mengkonsumsi kerang hijau dengan cara melakukan perendaman sebelum pengolahan.

2. Pemerintah dan pihak industri melakukan kontrol dengan cara melakukan pengolahan limbah (IPAL) sebelum dibuang ke badan air dengan mengacu pada baku mutu limbah.

3. Perlu dilakukan perendaman dengan menggunakan larutan asam belimbing wuluh (Hudaya, 2010), dan perendaman dengan larutan jeruk nipis (Wibowo, 2011) sebelum pengolahan terhadap kerang hijau.

\section{DAFTAR PUSTAKA}

Hudaya, R; 2010. Pengaruh Pemberian Belimbing Wuluh Terhadap Kadar Cadmium Pada Kerang Yang Berasal Dari Kenjeran Surabaya. Skripsi Universitas Airlangga : 73.

Murtini, J. T., Y. Yusma dan P. Rosmawaty, 2003. Kandungan Logam Berat Pada Kerang Darah, Air Laut Dan Sedimen di Perairan Tanjung Balai Dan Bagan Siapi-Api. Jurnal Perikanan Indonesia : 7.

Pranadita, Rendy, 2011. Studi Kandungan Logam Berat Cadmium Pada Beberapa Spesies Ikan, Moluska, Crustacea di Pantai Kenjeran, Surabaya Dan Branta Pesisir
Pamekasan, Madura. Skripsi Universitas Airlangga : 8.

Wibowo, Ahmad, 2011. Efektifitas Lama Waktu Perendaman Daging Kerang Hijau (Perna viridis) Dengan Larutan Asam Jeruk Nipis 25\% Dalam Menurunkan Logam Berat Kadmium (Cd).Thesis Universitas Diponegoro : 1.

Anwar, H., 1989. Sanitasi Makanan Dan Minuman Pada Institusi Pendidikan Tenaga Sanitasi. Jakarta, Departemen Kesehatan RI : 1.

Azwar, Azrul, 1995. Pengantar IImu Kesehatan Lingkungan. Jakarta, PT Mutiara Sumber Widya : 149.

Darmono, 2001. Lingkungan Hidup Dan Pencemaran. Jakarta, UI Press Jakarta : 178,105.

Gaman, P. M., K. B. Sherrington, 1994. Ilmu Pangan. Yogyakarta, Gadjah Mada University Press : 255.

H, Kristian, Retno, 2010. Kimia Anorganik Logam. Yogyakarta, Graha Ilmu : 323.

Kordi K, Ghufran, 2011. Budidaya 22 Komoditas Laut Untuk Konsumsi Lokal Dan Ekspor. Yogyakarta , Lily Publisher : 131.

Lu, Frank C, 1995. Toksikologi Dasar Asas, Organ Sasaran, dan Penilaian Risiko. Jakarta, Universitas Indonesia : 360.

Mukono, H.J, 2005. Toksikologi Lingkungan. Surabaya, Airlangga University Press : 213.

Notoadmodjo, Soekidjo, 2010. Metodelogi Penelitian. Jakarta, PT Rineka Cipta: 138.

Palar, Heryando, 2004. Pencemaran Dan Toksikologi Logam Berat. Jakarta, PT. Rineka Cipta : 23,124-132.

Permadi, Gilang, 2007. Pedagang Kaki Lima : Riwayatmu Dulu, Nasibmu Kinil,Yogyakarta, Yudhistira Ghalia Indonesia : 55.

Purnawijaya, Hiasinta A, 2001. Sanitasi Higiene Dan Keselamatan Kerja Dalam Pengolahan Makanan. Jakarta, Kanisius : 66-67.

Said, Ahmad, 2007. Sanitasi Higiene dan Keselamatan Kerja. Jakarta , PT. Sinar Wadja Lestari : 79. 
Sastrawijaya, Tresna, 2000. Pencemaran Lingkungan. Jakarta, PT. Adi Mahasatya : 53,104.

Slamet, Juli Soemirat, 1994. Kesehatan Lingkungan. Yogyakarta, Gadjah Mada University Press : 114.

SNI 7387:2009 tentang Batas Maksimum Cemaran Logam Berat Dalam Pangan. Jakarta.
Suparlan, 2012. Pengantar Pengawasan Hygiene-Sanitasi Tempat-Tempat Umum-Wisata\&Usaha-Usaha Untuk Umum. Surabaya, DuaTujuh : 161.

Tahir, Akbar, 2011. Ekotoksikologi Dalam Perspektif Kesehatan Ekosistem Laut. Bandung , Karya Putra Darwati : 33,57. 